\title{
Elderly women are at greater risk of comorbid generalised anxiety and depression than elderly men
}

Schoevers RA, Beekman AT, Deeg DJ, et al. Comorbidity and risk-patterns of depression, generalised anxiety disorder and mixed anxiety-depression in later life: results from the AMSTEL study. Int J Geriatr Psychiatry 2003;18:994-1001.

How prevalent are depression, generalised anxiety, and mixed anxiety/depression in elderly people and how similar are their risk factors?

\section{METHODS}

Design: Cross sectional study.

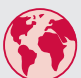

Setting: Amsterdam, The Netherlands; time period not specified.

으 People: 3790 people aged $65-86$ years old, living in the community. Participants were randomly sampled from 30 general practices. Adults with organic disorders were excluded.

$\Lambda$

Risk factors: Participants were interviewed to obtain information on: age, education level, socioeconomic status, marital status, social support, professional support, history of treatment for depression or generalised anxiety, or both, and presence of chronic disease (Cambridge Examination of Mental Disorders of the Elderly questions), cognitive status (Mini Mental State Examination (MMSE)), abilities in activities of daily living (ADL and Instrumental ADL (IADL) scales).

Outcomes: GMS-AGECAT diagnosis of pure depression (depression case level $\geqslant 3$ ), pure generalised anxiety (generalised anxiety case level $\geqslant 3$ ), or mixed anxiety/depression (both depression and generalised anxiety case levels $\geqslant 3$ ).

\section{MAIN RESULTS}

The prevalence of generalised anxiety was higher among people with depression (14.5\%) than in people without depression (1.3\%; p value

Table Odds ratios ( $95 \%$ confidence intervals) for risk factors identified by multivariate analysis

\begin{tabular}{|c|c|c|c|}
\hline Risk factor & Anxiety & Depression & $\begin{array}{l}\text { Anxiety/ } \\
\text { depression }\end{array}$ \\
\hline $\begin{array}{l}\text { History of } \\
\text { anxiety/ } \\
\text { depression }\end{array}$ & $\begin{array}{l}4.1 \\
(2.1 \text { to } 7.8)\end{array}$ & $\begin{array}{l}2.4 \\
(1.9 \text { to } 3.1)\end{array}$ & $\begin{array}{l}5.9 \\
(3.5 \text { to } 9.9)\end{array}$ \\
\hline Female sex & $\begin{array}{l}3.7 \\
(1.6 \text { to } 8.4)\end{array}$ & $\begin{array}{l}2.0 \\
(1.5 \text { to } 2.7)\end{array}$ & $\begin{array}{l}5.5 \\
(2.3 \text { to } 13.0)\end{array}$ \\
\hline IADL impairment & iNS & $\begin{array}{l}1.7 \\
(1.3 \text { to } 2.2)\end{array}$ & $\begin{array}{l}2.6 \\
(1.4 \text { to } 4.8)\end{array}$ \\
\hline ADL impairment & $\begin{array}{l}3.5 \\
(1.6 \text { to } 7.4)\end{array}$ & $\begin{array}{l}2.2 \\
(1.6 \text { to } 3.1)\end{array}$ & $\begin{array}{l}2.4 \\
(1.2 \text { to } 4.8)\end{array}$ \\
\hline $\begin{array}{l}\text { MMSE score } \\
<26\end{array}$ & $\begin{array}{l}2.6 \\
(1.3 \text { to } 5.2)\end{array}$ & $\begin{array}{l}1.4 \\
(1.1 \text { to } 1.9)\end{array}$ & $\begin{array}{l}2.2 \\
(1.2 \text { to } 4.1)\end{array}$ \\
\hline Unmarried & $\begin{array}{l}0.5 \\
(0.2 \text { to } 0.9)\end{array}$ & $\begin{array}{l}1.4 \\
(1.1 \text { to } 1.8)\end{array}$ & NS \\
\hline $\begin{array}{c}\text { Professional } \\
\text { support }\end{array}$ & NS & NS & $\begin{array}{l}1.8 \\
(1.0 \text { to } 3.2)\end{array}$ \\
\hline $\begin{array}{l}\text { Age over } 74 \\
\text { years }\end{array}$ & NS & NS & $\begin{array}{l}0.5 \\
(0.3 \text { to } 0.9)\end{array}$ \\
\hline
\end{tabular}

NS, not significant.

For correspondence: Dr R A Schoevers, A-opleiding Psychiatrie, Mentrum GGZ Amsterdam, Amsterdam, The Netherlands; robert.schoevers@ mentrum.nl

Sources of funding: not specified. not given); the same was true for the prevalence of depression in people with generalised anxiety $(60.4 \%$ in people with anxiety $v$ $10.8 \%$ in those without; $\mathrm{p}<0.0001$ ). The likelihood of comorbidity significantly increased with increasing severity of both depression and generalised anxiety $(\mathrm{p}<0.0001)$. Women showed significantly higher comorbidity then men (OR for mixed anxiety/depression 5.53, $95 \%$ CI 2.36 to 13.00 ). Risk profiles for pure and mixed diagnoses were similar (see table).

\section{CONCLUSIONS}

Depression and generalised anxiety show a high incidence of comorbidity, increasing in parallel to disease severity. Risk factors for the diagnoses of anxiety, depression, or mixed diagnosis were similar. Mixed anxiety/depression is much more frequent in women than in men.

\section{Commentary}

A re depression and anxiety distinct diagnostic entities, or do they represent different dimensions of a single disorder? Given the high estimates of comorbidity among psychiatric disorders, 't the question of whether any discrete psychiatric disorders exist at all warrants serious consideration. ${ }^{2}$ This may be of particular importance for older adult populations where the symptom expression of disorders such as depression may not fit into conventional diagnostic categories, thereby creating the illusion that depression declines with age. ${ }^{3}$ If symptom expression is different in old age in part because of different symptom clusters, dimensional scales of distress may be better at detecting mental health problems than diagnostic criteria. ${ }^{4}$

Using a large, representative community sample of older adults aged 65-84 years living in Amsterdam, Schoevers et al examine this issue of dimensionality versus binary classification of depression and anxiety. Their findings support the dimensionality approach. This work represents an important contribution over previous research in that it focuses specifically on older adults, and because it uses state of the art survey based methodology to examine the question using a non-institutionalised, community dwelling sample of adults.

With regard to clinical implications, their finding that women are much more likely to have mixed anxiety/depression is of particular interest. However, although their work is suggestive of the need to reconsider binary classifications, the treatment implications are not clear. Will, for example, these women with severe anxiety/depression respond to conventional therapies? If this end of the continuum represents the most advanced state, and therefore most severe form of the condition, will early detection and treatment of symptoms in this group prevent the onset of mixed depression/anxiety? These questions are in need of further investigation.

John Cairney, PhD

Assistant Professor and Research Scientist, Health Systems Research and Consulting Unit, Centre for Addiction and Mental Health, Department of Psychiatry, University of Toronto, Canada

1 Kessler RC, McGonagle KA, Zhao, et al. Lifetime and 12-month prevalence of DSM-IIIR psychiatric disorder in the United States. Results from the National Co-morbidity Survey. Arch Gen Psychiatry 1994;51:8-19.

2 Kessler RC. The categorical versus dimensional assessment controversy in the sociology of mental illness. J Health Social Behavior 2002:43:171-88.

3 Hocking LB, Koenig HG, Blazer DG. Epidemiology and geriatric psychiatry. In: Tsuang MT, Tohen M, Zahner GEP, eds. Textbook in psychiatric epidemiology. New York: Wiley-Liss, 1995:437-452.

4 Mirowsky J, Ross CE. Age and depression. J Health Soc Behar 1992;33:187-205 